\title{
Література:
}

1. Ночвіна О. А. Патогенетичні аспекти формування синдрому хронічного тазового болю у жінок репродуктивного віку. Wschodnioeuropejskie Czasopismo Naukowe. 2016. № 7, Ч. 1. C. 65-71.

2. The relationship between pelvic vein incompetence and chronic pelvic pain in women: systematic reviews of diagnosis and treatment effectiveness / R. Champaneria et al. Health Technology Assessment. 2016. Vol. 20, N 5. P. 1-108.

3. Волков А. Е. Эхосемиотика варикозного расширения вен малого таза. Эхография. 2000. Т. 1, № 1. С. 55-59.

DOI https://doi.org/10.30525/978-9934-26-075-9-11

\section{CHANGES IN THE CHARACTERISTICS OF THE GALLBLADDER IN PATIENTS WITH CHRONIC CHOLECYSTITIS AND COPD}

\author{
Dudka T. V. \\ Candidate of Medical Sciences, \\ Associate Professor at the Department of Internal Medicine, \\ Clinical Pharmacology and Occupational Diseases \\ Bukovinian State Medical University \\ Dudka I. V. \\ Candidate of Medical Sciences, \\ Associate Professor at the Department of Internal Medicine, \\ Clinical Pharmacology and Occupational Diseases \\ Bukovinian State Medical University \\ Pavlyuk V. O. \\ Deputy Head of the Department of Medical Assistance to the Population \\ Chernivtsi Regional State Administration Health Department \\ Chernivtsi, Ukraine
}

Different authors [2, p. 698] describe the development of gastric ulcer, gastric and duodenal erosions, chronic gastritis, duodenitis, reflux esophagitis and sliding hiatal hernia, duodenogastric reflux, changes in the liver, inflammation of the biliary tract and pancreas in the patients with chronic inflammatory diseases of the lungs and bronchi [4, p. 323]. Chronic acalculous cholecystitis (CAC) combined with chronic obstructive pulmonary disease 46 
(COPD), according to some authors, is known for the prevalence of aseptic inflammation in the gallbladder (GB), interrelation of exacerbations with COPD exacerbation [3, p. 2689] , more torpid, compared to COPD, and atypical course with less intensive pain syndrome, prevalence of dyskinetic phenomena over the inflammatory ones with formation of hypokinetic dyskinesias of the GB [1, p. 129].

Material and methods. 92 patients were involved in the study: 30 patients with COPD (1st group), 30 patients with COPD of comorbid CAC in the acute phase (2nd group), 32 patients with CAC in the acute phase (3rd group) and a control group - 30 practically healthy individuals (PHI) of the respective age. Ultrasonographic testing of the liver, the GB, and the pancreas was carried out in $100 \%$ of patients by means of an ultrasound scanner "Au-4 Idea» (Biomedica, Italy).

Results. Exploring the functional status of the gallbladder and sphincter apparatus of hepatobiliary system, during duodenal intubation typical features for changes of gallbladder dyskinesia were defined in all groups of patients. In particular, the duration of the first phase, which indicates that the basal secretion of bile in patients of the 3-rd group exceeded the rate in the practically healthy people $42,5 \%$ more $(p<0,05)$, while in patients of group $2-$ the results was the opposite. The phase was shorter $23,5 \%$ less $(p<0,05)$. Changes of patients in the 1-st group had a downward trend ( $>0,05)$. Our attention was attracted to the changes of the number of secreted bile: in all monitoring groups were found a significant increase in the volume of secreted bile, which exceeded the rate in respectively $1,9,1,6$ and 2,6 times $(p<0,05)$. In patients of the 1-st - 3-rd groups probable increase in the volume of secreted bile was also found, respectively in $3,4,4,3$ and 4,0 times $(\mathrm{p}<0,05)$ compared with normative data. Evidence of gallbladder dyskinesia in patients with chronic acalculous cholecystitis was the changes found when analyzing the data of the 4-th phase of duodenal intubation (gallbladder contraction). In particular, the duration of the 4-th phase in patients of the 1-st-3rd groups was significantly higher than in practically healthy people group, respectively in $1,7,2,1$ and 1,9 times $(\mathrm{p}<0,05)$, indicating the presence of hypokinetic gallbladder dyskinesia.

These data of duodenal intubation confirm the results of ultrasonographic examination of the gallbladder with the load of tryout breakfast by the standard method. According to the results obtained in patients of the 2-nd and the 3-rd groups, was established probable increase in size of the gallbladder: length $-43,2 \%$ and $25,7 \%$, respectively $(p<0,05)$, width $-29,2 \%$ and $17,9 \%$ $(p<0,05)$, respectively, while the changes in the length of the gallbladder in patients of the 1-st group were unlikely, and the width was also higher than in 
the practically healthy people group in $13,6 \%(\mathrm{p}<0,05)$. In patients of the 2 -nd and 3-rd groups were found compression and thickening of the gallbladder wall, particularly in patients of the 2-nd group in 3,1 times, the 3-rd group in 2,9 times $(\mathrm{p}<0,05)$.

Results of the study of the duration of the latent period of gallbladder contraction coincide with the data of duodenal intubation and indicate to its prolongation in patients of the 1-st, the 2-nd and the 3-rd groups respectively in $1,5,2,0$ and 1,8 times $(\mathrm{p}<0,05)$.

Conclusions. The findings, which have been obtained, allow us to state that more severe COPD causes higher degree of gallbladder hypokinetic dysfunction, biliary type hypertonic dysfunction of Oddi's sphincter, the activity in inflammatory process in the gallbladder, besides, the risk of gallstone formation, with predominant bile pigments and calcium in them, is bigger.

\section{References:}

1. Douglas W. Mapel, Jenõ P. Marton. Prevalence of renal and hepatobiliary disease, laboratory abnormalities, and potentially toxic medication exposures among persons with COPD. International Journal of Chronic Obstructive Pulmonary Disease. 2013; 8: 127-134.

2. Lin P.J., Shaya F.T., Scharf S.M. Economic implications of comorbid conditions among Medicaid beneficiaries with COPD. Respir Med. 2010; 104 (5) : 697-704.

3. Minakata Y., Ueda H., Akamatsu K., et al. High COPD prevalence in patients with liver disease. Intern Med. 2010;49 (24): 2687-2691.

4. Terzano C., Conti V., Di Stefano F., et al. Comorbidity, hospitalization, and mortality in COPD: results from a longitudinal study. Lung. 2010;188 (4): 321-329. 